\title{
Popper's Darwinian Analogy
}

\author{
Bence Nanay \\ University of Antwerp
}

Popper famously beld that the growth of scientific knowledge and the Darwinian mechanism of trial and error elimination are analogous processes. Both the validity of this analogy and Popper's interpretation of what this Darwinian mechanism consists in have been criticized. But it has been ignored that the use of Popper's Darwinian analogy had changed in the course of Popper's life. I will argue that until the 1960s, he used the Darwinian process as a model for understanding the growth of scientific knowledge, whereas from the 1960s on, the explanatory order was reversed: he used his new insights about the growth of scientific knowledge to say something about the real nature of Darwinian selection. In short, this analogy was so central for Popper's thinking that rather than giving up on it, he tried very hard to find theories of biological evolution that would make this analogy plausible. And this is what led him to make somewhat surprising claims about the nature of selection as well as to flirt with Lamarckism.

\section{Introduction}

One of the most deeply entrenched ideas in Popper's philosophy is the analogy between the growth of scientific knowledge and the Darwinian mechanism of natural selection. Popper gave his first exposition of these ideas very early on. In a letter to Donald Campbell, ${ }^{1}$ Popper says that the idea goes back at least to the early thirties. ${ }^{2}$ And he had a fairly detailed

1. Letters from Popper to Donald Campbell, 1964, February 3 and April 6, Popper archive, file number 282/12.

2. He is probably referring to the unpublished manuscript "Die Beiden Grundprobleme der Erkenntnistheorie," which he completed in 1932 (see Keuth 2005, pp. 2-3 on the fate of this unpublished book). It has been argued that Popper's general idea of describing the acquisition of knowledge in terms of a selection process (rather than in terms of in-

Perspectives on Science 2011, vol. 19, no. 3

(C)2011 by The Massachusetts Institute of Technology 
account of it in his "What is dialectic?", a talk given in 1937 and published in $1940:^{3}$

If we want to explain why human thought tends to try out every conceivable solution for any problem with which it is faced, then we can appeal to a highly general sort of regularity. The method by which a solution is approached is usually the same; it is the method of trial and error. Thus, fundamentally, is also the method used by living organisms in the process of adaptation. (Popper [1940] 1963, p. 312)

And here is the famous exposition of the general idea of the analogy between theory choice and natural selection in the Logic of Scientific Discovery:

How and why do we accept one theory in preference to others? [...] We choose the theory which best holds its own in competition with other theories; the one which, by natural selection, proves itself the fittest to survive. This will be the one which not only has hitherto stood up to the severest tests, but the one which is also testable in the most rigorous way. (Popper [1959] 2002, p. 91)

And he gave a detailed account of this analogy in his last book (Popper 1994). So it seems that the analogy between the growth of scientific knowledge and the Darwinian mechanisms of natural selection were central to his philosophy throughout his life.

In fact, I will argue that this analogy was so central that rather than giving up on it, Popper tried very hard to find theories of biological evolution that would make this analogy plausible. And this is what explains his often dismissed and misinterpreted flirtation with Lamarckism.

I will argue that until the 1960s, Popper used the Darwinian process as a model for understanding the growth of scientific knowledge. He took the Darwinian model for granted and applied it in the case of the growth of scientific knowledge. From the 1960s, the explanatory order was reversed. He no longer took the Darwinian model for granted, but rather used his new insights about the growth of scientific knowledge to figure out the real nature of Darwinian selection. And this led him to make some dubious and widely criticized claims about the biological domain (includ-

struction) goes even further back to debates over the right method to be used in the Austrian school system between 1925 and 1927. See Bartley 1974.

3. The paper was published in Mind in 1940 and reprinted as chapter 15 of Conjectures and Refutations. The most explicit statement of the evolutionary analogy is on pp. 312313. 
ing a rarely publicized unsuccessful attempt to publish in defense of Lamarckism in Nature).

The plan of this paper is the following. First, I outline the main similarities, as Popper perceived them, between the growth of scientific knowledge and the Darwinian mechanism for natural selection (Section II) and point out how Popper's picture of one side of this analogy, the growth of scientific knowledge, got more complex during the 1960s, arguably, as a result of his interaction with Lakatos and Zahar (Section III). I aim to point out how, in order to preserve the Darwinian analogy in the light of his new way of thinking about the growth of scientific knowledge, he had to reinterpret what he took to be the Darwinian model of natural selection (Section IV and V). Finally, I briefly examine whether and how the Darwinian analogy that Popper held to be so important could be salvaged in a biologically plausible manner (Section VI).

\section{The Darwinian Analogy}

There is no shortage of passages in Popper's writings that emphasize the similarities between the growth of scientific knowledge and the Darwinian mechanism for natural selection. The question is what these passages say about the nature of this similarity. The main point of analogy seems to be that both the growth of scientific knowledge and the Darwinian mechanisms are selection processes (to be contrasted with instruction): they consist of "random" (more on this soon) trials followed by errorelimination.

Here is how it works in the biological case. Selection is often ${ }^{4}$ described as repeated cycles of two separate processes. As Ernst Mayr says, "natural selection is actually a two-step process, the first one consisting of the production of genetically different individuals (variation), while the survival and reproductive success of these individuals is determined in the second step, the actual selection process (Mayr 1991, p. 68; see also Mayr 1978; 1982, pp. 519-520; 2001, p. 117). ${ }^{5}$ David Hull calls these two steps replication and interaction (Hull 1981; 1988; Hull et al. 2001). ${ }^{6} \mathrm{He}$ defines selection as:

4. But not always. Another influential way of describing selection is in terms of the heritable variation of fitness, see Godfrey-Smith 2007, Sober 1984, Okasha 2007, Lewontin 1970, Maynard Smith 1987 and Nanay forthcoming for a comparison of these two ways of thinking about selection.

5. Popper and Mayr had an extensive correspondence throughout most of their (long) careers. See Popper archive, file number 325/1.

6. As a Ph.D. student, Hull took Popper's class at Indiana University in 1963 and Popper was so impressed with him that he wrote a (very positive) letter of recommendation for him on June 2, 1964. Popper's letter of recommendation for Hull is in the Popper archive, file number 386/44. 
The repeated cycles of replication and environmental interaction so structured that environmental interaction causes replication to be differential. (Hull et al. 2001, p. 53)

Popper's claim is that this model also applies to the growth of scientific knowledge. Scientists form bald conjectures: this is the first step of replication (Hull) or variation (Mayr). And then they subject these conjectures to falsification: this is the second step of environmental interaction (Hull) or "actual selection" (Mayr).

Thus, as the selection process consists of two steps, the analogy between selection among scientific theories and natural selection could be broken down into two different aspects: (i) the analogy between the formation of conjectures and replication, and (ii) the analogy between falsification and environmental interaction. I will put (ii) aside, although it has been famously argued that this analogy is at best misleading: theories do not get falsified in the way organisms die; the death of theories is a slow death (see Lakatos 1970 for the most famous exposition of this idea). Note however that the Darwinian analogy does not imply that the second step of environmental interaction brings either death or survival. There can be selection even if the second step of environmental interaction only influences the number of offspring the competing organisms have (see, for example, Williams 1966). But the main focus of Popper's Darwinian analogy is not (ii), but (i).

Popper's original insight was that just as the first step of natural selection (replication, variation) is random, the conjectures of science are also random. And just as any kind of evolutionary change is only achieved with the contribution of the second step of selection (environmental interaction), the same is true for the growth of scientific knowledge, which could not happen without the second step of error-elimination.

And here we need to make a distinction between the early (pre-1960s) Popper and the late Popper. To state the difference very simply, the early Popper takes it for granted that mutation is random and concludes from the Darwinian analogy that conjectures are also random (see esp. Popper 1959, p. 31). The late Popper, in contrast, no longer takes conjectures to be (fully) random and looks for ways in which mutations could be interpreted as not (completely) random.

1 LINE SHORT

REGULAR

\section{Popper's Revisions of the Darwinian Analogy}

The original version of Popper's Darwinian analogy took the model of random variation from biology and applied it to the formation of conjectures. If this process is random, then there can be no logical analysis thereof. As Popper emphasizes in the Logic of Scientific Discovery: 
The act of conceiving a theory seems to me neither to call for logical analysis nor to be susceptible of it. The question how a new idea occurs to a man-whether it is a musical theme, a dramatic conflict, or a scientific theory-[ . . . $]$ is irrelevant to the logical analysis of scientific knowledge. (1959, p. 31)

Even in his first thorough and detailed exposition of the Darwinian analogy, "Evolution and the tree of knowledge," which was originally delivered as the Herbert Spencer lecture in Oxford in 1961 and mostly unchanged before its publication as Chapter Seven in Objective Knowledge in 1972, he repeatedly talks about "purely accidental co-operation of independent mutations" (Popper [1961] 1972, p. 273), "purely accidental mutation," "independent accidental mutations" (p. 270) and applies this model to the formation of scientific conjectures.

The problem is that random formation of conjectures just does not seem to be the way science proceeds and some important philosophers in Popper's circle in the 1960s were giving convincing arguments and thorough analyses of actual case studies that demonstrated this. The most important of these was Imre Lakatos.

Lakatos is very explicit that scientific research s are not sets of theories but "a temporal chain of sets of theories." If a scientific research programme faces an objection, it lives on (maybe acquiring a bit of a protective belt). In other words, scientific research programmes can and do change. The set of theories in a scientific research programme at time $t$ is different from the set of theories in it at some later time, $t^{*}$. And what set of theories we get in a research programme at time $t^{*}$ depends on what happens to the research programme at time t-what objections it faces and how it can handle them.

Thus, Lakatos's scientific research programmes can be gradually finetuned: the set of theories that comprise the research programme at time $t^{*}$ can deal with more objections than the set of theories at time $t$, which precedes $t^{*}$. The "mutations" of the research programme are not completely "blind" in the sense Popper thinks genetic mutations are blind: it is not the case that "the survival of a mutation cannot influence the further mutations" (Popper [1975] 1996, p. 5). In the case of a scientific research programme, the way it can deal with objections does influence what directions it develops into in the future.

Given how close Popper and Lakatos were intellectually in the mid1960 s, it is unlikely that these ideas would not have had an influence on Popper, especially given his claim about Lakatos: "I can say what I think

7. Lakatos 1970, 1974. Lakatos makes this especially clear in a letter to Yehuda Elkana in 1973: Lakatos to Yehuda Elkana, March 29, 1973. Lakatos archive, file number 13/250. 
about him in five words: He has revolutionized my thinking." ${ }^{.8}$ And Lakatos clearly thought that his ideas had influenced Popper: he wrote repeatedly (at least a dozen times) on the margins of various manuscripts by Popper that, "you are stealing from me." It is also likely that Lakatos's perception that Popper did not acknowledge his influence was the main cause of the serious fallout between the two philosophers in the early seventies. ${ }^{10}$

But Lakatos was not the only philosopher in Popper's circle in the 1960s who argued that the formation of conjectures is not to be compared to "purely accidental independent mutations." Others included Elie Zahar and John Worrall. Zahar argued that even the boldest conjectures could be given a logical analysis in gradualistic terms (see especially Zahar 1984), and Worrall (much later) gave a detailed case study of Fresnel's theory of diffraction, which shows that his conjectures were not at all random (Worrall 1995, pp. 92ff; see also Akeroyd 2004, pp. 390-393 for an alternative analysis).

To sum up, it seems that, under the influence of all these philosophers, Popper changed his mind about the completely random character of the formation of scientific conjectures some time in the 1960s. And this change was already reflected in his 1965 Compton lecture, where he writes:

The method of trial and error-elimination does not operate with completely chance-like or random trials [. . .], even though the trials may look pretty random. [. . .] For the organism is constantly learning from its mistakes, that is, it establishes controls which suppress or eliminate, or at least reduce the frequency of, certain possible trials (which were perhaps actual ones in its evolutionary past). (Popper $[1965] 1972$, p. 245 , n. 55$)^{11}$

8. Popper to Isaiah Berlin on 1964, Febr. 16, Lakatos Archive 13/736/65. Note that Popper often said that Lakatos has revolutionized the philosophy of mathematics (Lakatos confronts Popper with this in a letter in 1969, Lakatos archive, file number 13/736). But what he wrote to Berlin is something much stronger: that Lakatos revolutionized his thinking (not a sub-discipline).

9. Lakatos archive, file number 10/2, Lakatos archive, file number 15/90.

10. This fallout is well-documented (Lakatos archive, file number 13/736, Popper archive file number 318.4-10). Given the intellectual and personal closeness of the two philosophers, this turn of events is even more surprising-and the nominal reasons given (Lakatos used Popper's typist without Popper's authorization, Lakatos failed to give back the proofs of one of Popper's articles) clearly do not explain it.

11. Note that when John Worrall criticizes Popper for taking scientific conjectures to be completely random (Worrall 1995), he seems to apply this criticism to Popper's oeuvre in general, ignoring this famous footnote. 
Popper spent a lot of time in the next decade trying to spell out in what sense the formation of conjectures is random and in what sense it is not (some examples: Popper 1974b, p. 1061; 1978, p. 348; 1974a, p. 138; [1975] 1996, p. 3).

But if he no longer took the formation of scientific conjectures to be completely random, then how could he hold on to the Darwinian analogy? There are two options: first, he could limit the generality of the analogy and allow for the differences between mutations and conjectures while preserving the general structure of the analogy. And, second, he could revise the way of interpreting mutations in such a way that the analogy between conjectures and mutations is restored. Popper seems to have tried both of these strategies.

He made a number of attempts to clarify how the "more or less random" character of mutations is different from the "more or less random" character of conjectures. According to the most detailed such attempt, in his 1973 Herbert Spencer Lecture (Popper [1975] 1996, p. 5), mutations are (more or less) random and also blind, whereas conjectures are although still (more or less) random, they are not blind. This way of drawing the distinction seems to contradict his "Replies to my critics" (written in the same year as the Spencer lecture), where he describes scientific conjectures as blind and even elaborates on what this means and how it does not exclude goal-directedness (1974b, p. 1061). All of these distinctions and alleged clarifications, regardless of how problematic, ad hoc, or contradictory they may be, are only supposed to be supplementary to Popper's more fundamental reinterpretation of the Darwinian analogy. Popper recognized that the formation of scientific conjectures is not completely random and his insistence on the Darwinian analogy forced him to say the same about mutations. He did try to point out some important differences between the two processes, but these are supposed to be differences between two not completely random processes.

But then Popper had to reinterpret the theory of natural selection in such a way that mutations would come out as not completely random. And this required some adventures, not always very fortunate ones, into the domain of biology.

\section{Popper's Adventures into the Domain of Biology}

In the 1960s, Popper was apparently quite preoccupied with various questions in evolutionary biology. In 1963, he asks Campbell for all of his papers on evolutionary epistemology. ${ }^{12}$ In 1965 , Lakatos says in a letter to 
Marjorie Grene, somewhat despairingly, that "nowadays, [Popper's] main interest is evolution." ${ }^{13}$

The focus of Popper's interest was the question about how random mutations can explain the apparent teleology of the natural world. This theme appeared in his 1961 lecture:

[The difficulty evolutionary theory faces is] the difficulty of understanding how a complicated organ, such as the eye, can ever result from the purely accidental co-operation of independent mutations. (p. 273)

And, even more explicitly:

The real difficulty of Darwinism is the well-known problem of explaining evolutions which are apparently goal-directed such as that of our eyes, by an incredibly large number of very small steps; for according to Darwinism, each of these steps is the result of a purely accidental mutation. That all these independent accidental mutations should have had survival value is difficult to explain.

(pp. 269-270)

Popper tried to give an answer to this question in a number of ways. But it is important to note that the reason why he was interested in these questions about evolutionary biology was the need to reinterpret his Darwinian analogy. Two of his most infamous attempts to explain how adaptive evolution is possible in spite of the randomness of mutations were the "hopeful behavioural monsters hypothesis" (based on Goldschmidt 1940) and the "double spearhead hypothesis," which postulates two different kinds of genes that are subject to selection in different manner. Both of these ideas are already present in Popper [1961] 1972 (the latter in the original 1961 lecture, the former only in the addendum written before the publication in 1972).

Both of these ideas were (rightly) dismissed by Popper's contemporaries. So much so that Popper's close friend, Peter Medawar repeatedly discouraged Popper from publishing both the Spencer lecture and later the Compton lecture ("Of clouds and clocks" (Popper [1965] 1972), where he repeated the "double spearhead hypothesis." Ernst Mayr was equally negative: "To be very frank, I was not too happy with your treatment of

13. Lakatos to Marjorie Grene, 31 December 1965, Lakatos archive, file number $13 /$ 346. Lakatos thanks Grene for sending him her article "Beyond Darwinism," and he writes: "I wonder whether you sent a copy to Karl Popper who I am sure would be very interested to read it. Nowadays his main interest is evolution."

14. Peter Medawar to Popper, 1965, March 29; Peter Medawar to Popper 1966, August 16; both in Popper Archive, file number 325/26. It is Medawar who Popper refers to 
natural selection in the essay you wrote in Objective Knowledge." ${ }^{15}$ Popper seems to have abandoned his "behavioural monster" idea, but he did reiterate the "double spearhead hypothesis" throughout the rest of his life, even in his 1994 Knowledge and the Body-Mind Problem. What this lead to was a certain amount of bewilderment and mistrust towards Popper's ideas on behalf of biologists (see Hull 1999 for a thorough summary, but see also Settle 1996). As John Worrall summarizes, Popper "interprets 'selection' in a way that is, to say the least, rather unorthodox" (1995, p. 102).

\section{Popper and Lamarck}

The most important, and often ignored, attempt on Popper's behalf to restore his Darwinian analogy was his insistence on the quasi-Lamarckian character of both natural selection and the growth of scientific knowledge. It is important to note that he never explicitly confessed to Lamarckism, but suggested that Darwinian selection processes simulate, or resemble, Lamarckian evolution. He reiterates this suspiciously many times (Popper 1972, pp. 149, 245, 268, 272; 1973; Popper 1974a, p. 138; 1994, p. 70). He even writes in a letter to Mayr (who was pushing him on his Lamarckian leanings) that "I am a more orthodox Darwinist than Darwin [. . .] who believed in the occasional inheritance of acquired characters." 16

It has been argued that Popper uses the labels of Darwinism and Lamarckism somewhat misleadingly (Hull 1999, p. 492). Maybe a better distinction for Popper's purposes would have been the one between soft and hard inheritance (see Mayr 1982, p. 687ff). But Popper's general idea is simple: in the case of Lamarckian evolution, the first step in the selection process (conjecture, replication) is guided by the second step of the previous cycle (falsification, environmental interaction). In the case of Darwinian selection, it is not. Let us see what this contrast amounts to and why Popper turned to Lamarck to begin with.

Let us summarize the problem Popper faces. In the case of the growth of scientific knowledge, it seems that the new trials are influenced by the errors committed previously. Popper is quick to admit this, already in his Compton lecture:

The method of trial and error-elimination does not operate with completely chance-like or random trials [...], even though the trials may

at the beginning of the Addendum to the Spencer lecture, as the expert who tried to discourage him from publishing it and not Mayr, as Hull (1999, p. 490) suggests.

15. Ernst Mayr to Popper 1979, July 31, Popper archive, file number 325/1.

16. Popper to Ernst Mayr, 1977, April 18, Popper Archive, file number 551/4. 
look pretty random. [. . .] For the organism is constantly learning from its mistakes, that is, it establishes controls which suppress or eliminate, or at least reduce the frequency of, certain possible trials (which were perhaps actual ones in its evolutionary past. (โ1965] 1972 , p. 245 , n. 55)

But this is clearly not what is happening in the case of gene-based natural selection. The way Popper understands gene-based natural selection is very different. He writes in 1975 :

[evolutionary] theory predicts accidental mutations and thus accidental changes. [. . .] Thus we should expect evolutionary sequences of the random-walk type. (1974a, p. 138, Popper's emphasis)

And, even more explicitly:

The survival of a mutation cannot influence the further mutations, not even the frequencies or probabilities of their occurrence.

([1975] 1996, p. 5)

Thus, if we want to maintain the analogy between natural selection and the growth of scientific knowledge, we need to reinterpret gene-based selection. And Popper's idea is that although mutations are not informed by the previous cycle of error-elimination (like Popper's interpretation of Lamarckism would have it), they work as if they were informed by the previous cycle of error-elimination. Again, the intention is that this picture is not Lamarckian, it is still Darwinian, but it simulates Lamarckian evolution.

There are two different attempts to flirt with the idea of Lamarckian evolution in Popper's writings in the 1960s and 1970s. The first one is not too radical -it is basically a revision of the old idea of the Baldwin effect: a process whereby an organism changes the environment thereby influencing the selection pressures in the next generation (Baldwin 1902; see also Belew-Mitchell 1996; Weber-Depew 2003; and Godfrey-Smith 2003 for discussion). As Popper summarizes:

New pressures, new challenges and new problems may arise as a result of the structural changes which have arisen from within the organism. ([1975] 1996, p. 4; see also Popper [1961] 1972, pp. 268, 270; [1965] 1972, p. 245, n. 56)

Although the point could be made that Popper somewhat exaggerated the importance and frequency of the occurrences of the Baldwin effect, it is at least not problematic from a biological point of view (see Godfrey-Smith 
2003 for a good summary). And the Baldwin effect does exactly what Popper needed: simulates Lamarckian evolution within the Darwinian framework. But Popper realized soon that his appeal to the Baldwin effect will not be general enough. And this is when he turned to a more radical version of Lamarckism.

In 1967, Popper wrote to Lakatos: "You will be thrilled to hear what I have to tell you about the connection of our common philosophy and the great Break-through in Biology." ${ }^{\prime 17}$ Popper did not elaborate on what this connection is supposed to be, but from the collection of his clippings at that time, it seems likely that he was referring to the "central dogma of molecular biology" literature on transcription from RNA to DNA that Popper took to question the framework of Weismannian (as opposed to Lamarckian) evolution. ${ }^{18}$ Popper was interpreting this literature to show that the flow of information is not unidirectional from the DNA to the RNA, which he presumably interpreted as going against the Weismannian orthodoxy that the germ-line is never influenced by whatever happens to the organism during its life. If this were so, then gene-based selection would be more similar to the quasi-Lamarckian process of selection in the domain of scientific theories-the analogy between gene-based and scientific selection would be restored.

He used much of this literature in an unpublished manuscript "Lamarckism and DNA" (Popper 1973), which he submitted to Nature and got rejected. "Lamarckism and DNA" is an attempt to revive "molecular Lamarckism": the possibility of the inheritance of acquired characters in the light of recent contemporary findings of molecular biology. Popper is somewhat cautious: he does not argue that there is a mechanism for the inheritance of acquired characters but that we cannot exclude the possibility of such a mechanism. And Popper is also cautious as his conclusion is not strictly speaking Lamarckian. He concludes on a somewhat vague note that "this is not Lamarckism, but would in some respect resemble it" (1973). After Nature had rejected the manuscript, Popper abandoned it completely (see Aronova 2007, p. 44); however, he did not abandon the general idea of reviving something like Lamarckism.

Popper's enthusiasm for this way of salvaging the Darwinian analogy reached a new high when he read Edward Steele's book Somatic Selection and Adaptive Evolution (โ1979] 1981), which is an explicit attempt to revive

17. Popper to Lakatos, 1967, January 9, Popper archive file number 318.4-10, Lakatos archive, file number $13 / 736$.

18. Among his clippings from this period are three Encyclopaedia entries on Weismann (one from the 1967 Encyclopaedia Britannica) as well as lots of photocopies from 
the Lamarckian theoretical framework of selection. Popper was very enthusiastic about the book ${ }^{19}$ and wrote a very positive review in the Times Literary Supplement, where he describes Steele's book as "the most exciting scientific book which I had read for a very long time" and, importantly, concludes that "Steele shows that, in the light of molecular virology, both Darwin and Lamarck may have been right" (Popper 1979, p. 5). But Popper gets even closer to a straight endorsement of Lamarckism when he writes to Steele in a letter that "a kind of Lamarckism is compatible with modern genetic findings. ${ }^{20}$

Needless to say that this quasi-Lamarckian turn did not go down well with biologists (again, see Hull 1999 for a summary). To make things worse, Steele's book was based on experiments that were very controversial methodologically even at the time when Popper's review appeared (see Aronova 2007, pp. 45-47 for a good overview).

To sum up, we can say that Popper's revived and modified Darwinian analogy of the 1970s, where gene-based natural selection is modelled on the analogy of the growth of scientific knowledge, was not at all more successful than his original analogy where the growth of scientific knowledge was modelled on the analogy of gene-based selection.

Should we conclude that Popper's entire idea of the analogy between gene-based natural selection and the growth of scientific knowledge was mistaken? This is the question I briefly examine in the last section.

\section{Much Ado about Nothing?}

Popper's idea of the analogy between gene-based natural selection and the growth of scientific knowledge has been extremely influential. Besides the evolutionary epistemology movement (see,for example, Campbell 1956, 1960, 1974; Toulmin 1967, 1970, 1972; Kantorovich 1989; Bradie 1986), it has influenced much of the meme theory literature (Dawkins 1989, 1982a, 1982b; Dennett 1995; Aunger 2000, 2002) and especially David Hull's specific version of the selection among scientific theories ${ }^{21}$ (Hull 1988, 2001; cf. Bechtel 1988; Ghiselin 1988; and Griesemer 1988 for a variety of objections to his account) as well as Bas van Fraassen's Darwinian model for an antirealist explanation for the success of science (Van Fraassen 1980, p. 40). ${ }^{22}$

But I aimed to point out that Popper held two very different versions of

the "the central dogma of molecular biology" literature. Popper archive, file number 384/ 12. 
the Darwinian analogy at different points of his life and both of them are extremely problematic: one of them as a description of the growth of scientific knowledge and the other as a biological theory. Was Popper then completely wrong about the Darwinian analogy in general? And were the ones who followed Popper's lead and endorsed a version of this analogy also completely wrong? I do not want to endorse the Darwinian analogy, nor do I want to rule it out as hopeless. What I aim to do in this section is to give a more viable and plausible version of it than the ones I have identified in Popper's thinking.

My claim is that gene-based natural selection in fact works in a very similar way as Lakatos conceives of the growth of scientific knowledge: as a process whereby changes in the previous generation influence the next round of mutation. In fact, David Hull's widely (but not universally, see footnote 4 above) accepted definition of selection reflects this requirement:

The repeated cycles of replication and environmental interaction $s o$ structured that environmental interaction causes replication to be differen-

tial. (Hull et al. 2001, p. 53, my emphasis)

Take the following, very simplified, example. Suppose that an organism, $a$, is 12 feet tall. It has three offspring, $b, c$, and $d$, which are 10,12 , and 14 feet tall, respectively. The selection pressure is such that short individuals are selected against: $b$ and $c$ dies, and $d$ survives. Now, and this is the crucial point, the offspring of the surviving $d$ will tend to have the average height of 14 feet. Suppose that $d$ also has three offspring: $e, f$, and $g$, which are 12, 14, and 16 feet tall, respectively. Again, if short organisms are selected against, then $g$ will survive and its offspring are going to be even taller. Here evolution has what Popper would call "a direction" (Popper 1974a, p. 138), but we can explain that without any appeal to either Lamarckian or quasi-Lamarckian processes or the "double spearhead hypothesis."

So where did Popper go wrong? He described gene-based natural selection as "purely accidental co-operation of independent mutations" ([1961] 1972 , p. 273) and then spent a lot of time trying to specify in what sense mutations are "accidental" or "random." But the problem is not with the claim that mutations are accidental but with the claim that they are independent. A mutation in my mother's genes will influence the outcome of the mutations of my genes inasmuch as my genes that get mutated are the result of the mutation of my mother's genes. In this sense, mutations are not independent at all.

class at Indiana University in 1963 and Popper wrote a (very positive) letter of recommendation for him in 1964. 
Or, to use another one of Popper's explicit statements, he says that in the case of gene-based natural selection, "the survival of a mutation cannot influence the further mutations, not even the frequencies or probabilities of their occurrence" ([1975] 1996, p. 5). This is false, for the reasons just given. It is true that the survival of a mutation does not influence to what direction or with what probability a further mutation happens. But it does influence what will mutate: it influences what will serve as the basis for this mutation.

Can we then restore Popper's Darwinian analogy in a non-Popperian manner? I want to be careful here. If we accept that the growth of scientific knowledge works the way Lakatos describes it (and the way Popper describes it in his Compton lecture, esp. Popper [1965] 1972, p. 245 , n. 55), then there is an analogy between gene-based natural selection and the growth of scientific knowledge: in both cases the entities that survive error-elimination are the ones that provide the starting point for the next round of trials, and in that sense the survival of a mutation does influence further mutations. Selection is cumulative in both cases. ${ }^{23}$

But it is a different, and much more complicated, question whether this analogy or, rather, this similarity in a specific respect, is explanatory. Stephen Toulmin, another early proponent of the Darwinian analogy, repeatedly argued that this analogy is explanatory (see esp. Toulmin 1967; see also Toulmin 1970, pp. 560-566 and Toulmin 1972, but see Lakatos's demolition of Toulmin's argument in Lakatos 1976). Popper also took the analogy to be explanatory: he thought that we gain some genuine insight into the way scientific knowledge grows if we take the Darwinian analogy seriously. My aim here is not to argue that the Darwinian analogy is in fact explanatory. I am making a much more modest, conditional, claim: if one intends to use the Darwinian analogy to explain the growth of scientific knowledge, the version of the analogy I sketched in this section is a better bet than the two (very different) versions that Popper considered. ${ }^{24}$

22. Van Fraassen explicitly acknowledges the influence of Popper's "The rationality of scientific revolutions" paper I discussed above, especially its sections I-VI and VIII. Personal communication with Van Fraassen, August 26, 2006.

23. This may explain why Popper overlooked this simple way of salvaging the Darwinian analogy and looked for much more complicated and more problematic solutions. Popper often contrasted "cumulative" and "revolutionary" as attributes of scientific change (see for example, Popper [1975] 1996, p. 12) and he took scientific change to be the latter. It is important that Popper's contrast between "cumulative" and "revolutionary" is similar to his contrast between instruction and selection. Hence, it would have been possible for him to allow for the possibility of a selection process that is cumulative in the sense that every small step in this process would consist of trial and error-elimination, but these steps follow each other in a cumulative manner-which is exactly the way biologists describe the process of natural selection.

1 LINE SHORT

REGULAR 


\section{References}

Akeroyd, F. Michael. 2004. "Popper's Evolutionary Epistemology Revamped." Journal for General Philosophy of Science 35: 385-396.

Aronova, Elena. 2007. "Karl Popper and Lamarckism." Biological Theory 2: $37-51$.

Aunger, Robert (ed.). 2000. Darwinizing Culture. The Status of Memetics as a Science. Oxford: Oxford University Press.

Aunger, Robert. 2002. The Electric Meme: A New Theory of How We Think and Communicate. New York: Free Press.

Bartley, W. W. 1974. "Theory of Language and Philosophy of Science as Instruments of Educational Reform: Wittgenstein and Popper as Austrian Schoolteachers." Pp. 307-337 in Methodological and Historical Essays in the Natural and Social Sciences. Edited by Cohen, R. S. and Wartofsky, M. W. Dordrecht: Reidel.

Bechtel, William. 1988. "New Insights into the Nature of Science: What Does Hull's Evolutionary Epistemology Teach Us." Biology and Philosophy 3: 157-164.

Bradie, Michael. 1986. "Assessing Evolutionary Epistemology.” Biology $\mathcal{E}$ Philosophy, 1: 401-459.

Brandon, Robert N. 1990. Adaptation and Environment. Princeton: Princeton University Press.

Brown, James Robert. 1985. "Explaining the Success of Science." Ratio 27: 49-66.

Campbell, Donald. 1974. "Evolutionary Epistemology." Pp. 413-463 in The Philosophy of Karl Popper. Edited by In: Schilpp, Paul A. LaSalle: Open Court.

Campbell, Donald T. 1956. "Perception as Substitute Trial and Error." Psychological Review 63: 331-342.

Campbell, Donald T. 1960. "Blind Variation and Selective Retention in Creative Thought as in Other Knowledge Processes." Psychological Review 67: 380-400.

Campbell, Donald T. 1988. "A General 'Selection Theory', as Implemented in Biological Evolution and in Social Belief-Transmition-withModification in Science." Biology and Philosophy 3: 171-177.

Dawkins, Richard. (1976) 1989. The Selfish Gene, Second edition, Oxford University Press, Oxford.

Dawkins, Richard. 1982a. The Extended Phenotype, W. H. Freeman, Oxford.

Dawkins, Richard. 1982b. "Replicators and Vehicles." Reprinted in: Brandon, R. N. and Burian, R. M. (eds.), Genes, Organisms, Populations: Controversies over the Units of Selection, The MIT Press, Cambridge, Mass, 1984. 
Dawkins, Richard. 1983. "Universal Darwinism," Pp. 403-425 in Evolution from Molecules to Man. Edited by Bendall, D. S. Cambridge University Press, Cambridge.

Dennett, Daniel C. 1995. Darwin's Dangerous Idea, Touchstone, New York.

Dennett, Daniel C. 2003. Freedom Evolves. New York: Viking, 2003.

Dennett, Daniel C. 2006. Breaking the Spell: Religion as a Natural Phenomenon. New York: Viking.

Ghiselin, Michael T. 1988. "Science as a Bioeconomic System." Biology and Philosophy 3: 177-178.

Godfrey-Smith, Peter. 2003. "Between Baldwin Scepticism and Baldwin Boosterism." Pp. 53-68 in Evolution and Learning: The Baldwin Effect Reconsidered. Cambridge. Edited by Bruce H. Weber and David J. Depew. MA: The MIT Press.

Godfrey-Smith, Peter. 2007. "Conditions for Evolution by Natural Selection." Journal of Philosophy 104: 489-516.

Goldschmidt, Richard B. 1940. The Material Basis of Evolution. New Haven: Yale University Press.

Hull, David L. 1980. "Individuality and Selection," Annual Review of Ecology and Systematics 11: 311-32.

Hull, David L. 1981. "Units of Evolution: A Metaphysical Essay." Pp. 2344 in The Philosophy of Evolution. Edited by Jensen, U. J. and Harré, R. Harvester Press, Brighton.

Hull, D. L. 1988. "A Mechanism and Its Metaphysics: An Evolutionary Account of the Social and Conceptual Development of Science." Biology E Philosophy 3:123-155

Hull, David L. 1999. "The Use and Abuse of Sir Karl Popper." Biology and Philosophy 14: 481-504.

Hull, David L. 2001. Science and Selection, Cambridge University Press, Cambridge.

Hull, D. L., Langman, R. E., and Glenn, S. S. 2001. "A General Account of Selection: Biology, Immunology and Behavior," Behavioral and Brain Sciences 24: 511-528. Reprinted in Hull, David L. (2001).

Kantorovich, A. 1989. "A Genotype-Phenotype Model for the Growth of Theories and the Selection Cycle in Science." Pp. 171-184 in Issues in Evolutionary Epistemology. Edited by K. Hahlwed and C. A. Hooker. Albany: State University of New York Press.

Keuth, Herbert. 2005. The Philosophy of Karl Popper. Cambridge: Cambridge University Press.

Lakatos, Imre. 1970. "Falsification and the Methodology of Scientific Research Programmes." In Criticism and the Growth of Knowledge. Edited by Imre Lakatos and Alan Musgrave. Cambridge: Cambridge University Press. 
Lakatos, Imre. 1974. "Science and Pseudoscience." Pp. 96-102 in Philosophy in the Open. Edited by Godfrey Vesey. Milton Keynes: Open University Press.

Lakatos, Imre. 1976. "Understanding Toulmin." Minerva 14: 126-43.

Lewontin, R. 1970. "The Units of Selection." Annual Review of Ecology and Systematics 1: 1-18.

Maynard Smith, J. 1987. "How to Model Evolution." Pp. 119-131 in The Latest on the Best. Edited by Dupré, J. A. Cambridge, MA: The MIT Press.

Mayr, Ernst. 1978. "Evolution," Scientific American 239: 46-55.

Mayr, Ernst. 1982. The Growth of Biological Thought. Cambridge, MA: Harvard University Press.

Mayr, Ernst. 1991. One Long Argument: Charles Darwin and the Genesis of Modern Evolutionary Thought. Cambridge, MA: Harvard University Press.

Mayr, Ernst. 2001. What Evolution Is. New York: Basic Books.

Nanay, Bence. 2002. "The Return of the Replicator: What is Philosophically Significant in a General Account of Replication and Selection?" Biology and Philosophy 17: 109-121.

Nanay, Bence. 2010. "Rational Reconstruction Reconsidered." The Monist 93: 595-615.

Nanay, Bence. (forthcoming) "Replication without Replicators." Synthese

Okasha, S. 2007. Evolution and the Levels of Selection. Oxford: Oxford University Press.

Popper, Karl R. (1959) 2002. The Logic of Scientific Discovery. London Routledge.

Popper, Karl R. 1963. Conjectures and Refutations. London Routledge.

Popper, Karl, R. 1972. Objective Knowledge. Oxford: Clarendon.

Popper, K. R. 1973. "Lamarckism and DNA." Manuscript. Popper Archive, file number $128 / 4$.

Popper, Karl, R. 1974a. "Darwinism as a Metaphysical Research Programme." Pp. 133-143 in The Philosophy of Karl Popper. Edited by P. A. Schilpp. La Salle, IL: Open Court.

Popper, Karl, R. 1974b. "Replies to My Critics." Pp. 961-1197 in The Philosophy of Karl Popper. Edited by P. A. Schilpp. La Salle, IL: Open Court.

Popper, Karl, R. (1975) 1996. "The Rationality of Scientific Revolutions". Pp. 72-101 in Problems of Scientific Revolutions. Edited by R. Harré. Oxford: Clarendon. Reprinted in Popper, Karl, R.: The Myth of the Framework. London: Routledge, 1996.

Popper, Karl, R. 1978. "Natural Selection and the Emergence of Mind." Dialectica 32: 339-355. 
Popper, K. R. 1979. Review of E. J. Steele's "Somatic Selection and Adaptive Evolution." Times Literary Supplement (November 23, 1979), p. 5.

Popper, K. R. 1994. Knowledge and the Body-Mind Problem. London: Routledge.

Settle, Tom. 1996. "Six Things Popper Would Like Biologists not to Ignore." Biology and Philosophy 11: 141-159.

Sober, Elliott. 1984. The Nature of Selection. Cambridge, MA: MIT Press.

Steele, E. J. (1979) 1981. Somatic Selection and Adaptive Evolution. Chicago: University of Chicago Press (originally published at Toronto: Williams and Wallace in 1979).

Toulmin, Stephen. 1967. "The Evolutionary Development of Natural Science." American Scientist 55: 456-471.

Toulmin, Stephen. 1970. "From Logical Systems to Conceptual Populations." Boston Studies in the Philosophy of Science 8: 552-564.

Toulmin, Stephen. 1972. Human Understanding. Oxford: Clarendon.

Van Fraassen, Bas. 1980. The Scientific Image. Oxford: Oxford University Press.

Warnock G. J. 1960. Review of "The Logic of Scientific Discovery.” Mind 69: 99-101.

Weber, Bruce H. and David J. Depew. 2003. Evolution and Learning: The Baldwin Effect Reconsidered. Cambridge, MA: The MIT Press

Williams, G. C. 1966. Adaptation and Natural Selection. Princeton: Princeton University Press.

Worrall, John. 1995. "'Revolution in Permanence': Popper on TheoryChange in Science." Pp. 75-102 in Karl Popper: Philosophy and Problems. Edited by Anthony O'Hear. Cambridge: Cambridge University Press.

Zahar, Elie. 1984. "Logic of Discovery or Psychology of Invention?" British Journal for the Philosophy of Science 35: 243-261. 